\title{
Sphingosine Suppresses Mesothelioma Cell Proliferation by Inhibiting PKC- $\delta$ and Inducing Cell Cycle Arrest at the $\mathbf{G}_{0} / \mathrm{G}_{1}$ Phase
}

Hisaya Okuwaa,be Takeshi Kanno a,e Yumiko Fujitaa Akinobu Gotoh ${ }^{\mathrm{a}}$ Chiharu Tabata $^{b}$ Kazuya Fukuoka ${ }^{d}$ Takashi Nakano $^{\text {bd }}$ Tomoyuki Nishizakia

aDivision of Bioinformation, Department of Physiology, Hyogo College of Medicine, 1-1 Mukogawacho, Nishinomiya; bivision of Pulmonary Medicine, Department of Internal Medicine, Hyogo College of Medicine, 1-1 Mukogawa-cho, Nishinomiya; 'Laboratory of Cell and Gene Therapy, Institute for Advanced Medical Sciences, Hyogo College of Medicine, 1-1 Mukogawa-cho, Nishinomiya; ${ }^{\text {CCancer }}$ Center, Hyogo College of Medicine, 1-1 Mukogawa-cho, Nishinomiya; eH. Okuwa and T. Kanno contributed equally to this work

\section{Key Words}

Sphingosine $\cdot$ Protein kinase $C-\delta \cdot$ Mesothelioma cell $\bullet$ Proliferation $\bullet$ Suppression

\begin{abstract}
Background/Aims: Sphingosine regulates cellular differentiation, cell growth, and apoptosis. The present study aimed at understanding sphingosine-regulated mesothelioma cell proliferation. Methods: Human malignant mesothelioma cells such as NCI-H28, NCI-H2052, $\mathrm{NCI}-\mathrm{H} 2452$, and MSTO-211H cells were cultured. The siRNA to silence the protein kinase $C$ (PKC)- $\delta$-targeted gene was constructed and transfected into cells. MTT assay, cell cycle analysis using a flow cytometry, and cell-free PKC- $\delta$ assay were carried out. Results: For all the cell types sphingosine inhibited cell growth in a concentration (1-100 $\mu \mathrm{M})$-dependent manner. The sphingosine effect was not prevented by rottlerin, an inhibitor of protein kinase $C-\delta$ (PKC- $\delta$ ); conversely, rottlerin further enhanced the sphingosine effect or rottlerin suppressed mesothelioma cell growth without sphingosine. In the cell-free PKC assay, sphingosine attenuated PKC- $\delta$ activity. Knocking-down PKC- $\delta$ induced cell cycle arrest at the $G_{0} / G_{1}$ phase and inhibited cell growth. Conclusion: The results of the present study show that sphingosine suppressed mesothelioma cell proliferation by inhibiting PKC $\delta$, to induce cell cycle arrest at the $G_{0} / G_{1}$ phase.
\end{abstract}




\section{Introduction}

Sphingolipids include ceramide, ceramide 1-phosphate, sphingosine, and sphingosine 1-phosphate (S1P). Sphingosine is produced from ceramidase-catalyzed cleavage of fatty acids from ceramide. Evidence has pointed to the role of sphingolipid in the regulation of cellular differentiation, cell growth, and apoptosis. We have earlier found that sphingosine induces apoptosis in hippocampal neurons and astrocytes by activating caspase-3/-9 via a sphingosine-dependent protein kinase (SDK)/14-3-3 protein/Bax/cytochrome c pathway $[1]$. SDK is produced through proteolytic processing of protein kinase C- $\delta(\mathrm{PKC}-\delta)$ and activated by binding sphingosine [2]. SDK specifically phosphorylates 14-3-3 protein [3, 4], thereby dissociating Bax from a complex with 14-3-3 protein, to induce a mitochondriamediated apoptosis. Sphingosine, alternatively, induces apoptosis in rhabdomyosarcoma cells by activating caspase-3/-9 in a Bax-dependent manner [5] or in mouse BALB/c 3T3 clone A31 cells in an SDK-dependent manner [2]. In our recent study, sphingosine induced apoptosis in well differentiated MKN-28 human gastric cancer cells by increasing SDK production from PKC- $\delta$, to phosphorylate 14-3-3 protein, thereby causing disruption of mitochondrial membrane potentials and activating caspase- 9 followed by the effector caspase-3. Sphingosine, thus, might be a target for development of anti-tumor drugs.

Malignant mesothelioma is an aggressive tumor arised from previous asbestos exposure. A great deal of challenge has been attempted, yet disappointingly, malignant mesothelioma is considerably resistant to conventional anticancer therapies and no beneficial effect is expected. Then, we were prompted to assess the effect of sphingosine on proliferation of malignant mesothelioma cells. We show here that sphingosine suppresses mesothelioma cell proliferation by inhibiting PKC- $\delta$, to induce cell cycle arrest at the $G_{0} / G_{1}$.

\section{Materials and Methods}

\section{Cell culture}

NCI-H28, NCI-H2052, NCI-H2452, and MSTO-211H cell lines were purchased from American Type Culture Collection (Manassas, VA, USA). Cells were grown in RPMI-1640 medium supplemented with 10\% $(\mathrm{v} / \mathrm{v})$ heat-inactivated fetal bovine serum, $0.003 \%(\mathrm{w} / \mathrm{v})$ L-glutamine, penicillin (final concentration, 100 $\mathrm{U} / \mathrm{ml}$ ), and streptomycin (final concentration, $0.1 \mathrm{mg} / \mathrm{ml}$ ), in a humidified atmosphere of $5 \% \mathrm{CO}_{2}$ and $95 \%$ air at $37^{\circ} \mathrm{C}$.

\section{Assay of cell viability}

Cell viability was assayed by the method using 3-(4,5-dimethyl-2-thiazolyl)-2,5-diphenyl-2Htetrazolium bromide (MTT) as described previously [1]. MTT-reactive cells were quantified at an absorbance of $570 \mathrm{~nm}$ using a micro-plate reader (SPECTRAmax PLUS384, Molecular Devices, Sunnyvale, CA, USA).

\section{Cell cycle analysis}

Cells were harvested by a trypsinization, fixed with $70 \%(\mathrm{v} / \mathrm{v})$ ethanol at $4{ }^{\circ} \mathrm{C}$ overnight. Fixed cells were incubated in phosphate-buffered saline containing $1.5 \mu \mathrm{g} / \mathrm{ml}$ RNase A for $1 \mathrm{~h}$ at $37^{\circ} \mathrm{C}$, followed by staining with $5 \mu$ l of propidium iodide (PI) for 20 min on ice. Then, cells were collected on a nylon mesh filter (pore size, $40 \mu \mathrm{m}$ ), and cell cycles were assayed using a flowcytometer (FACSCalibur, Becton Dickinson, USA) at an excitation of $488 \mathrm{~nm}$ and an emission of $585 \mathrm{~nm}$, and analyzed using FlowJo software (TreeStar, San Carlos, CA, USA).

\section{Cell-free PKC- $\delta$ assay}

PKC activity in the cell-free systems was quantified by the method as previously described [6]. Briefly, synthetic PKC substrate peptide $(10 \mu \mathrm{M})$ was reacted with PKC- $\delta$ in a $\mathrm{Ca}^{2+}$-free medium containing 20 $\mathrm{mM}$ Tris- $\mathrm{HCl}$ (pH 7.5), $5 \mathrm{mM}$ Mg-acetate, and $10 \mu \mathrm{M}$ ATP with and without sphingosine in the absence of phosphatidylserine and diacylglycerol at $30^{\circ} \mathrm{C}$ for $5 \mathrm{~min}$. After loading on a reversed phase high performance liquid chromatography (HPLC)(LC-10ATvp, Shimadzu Co., Kyoto, Japan), a substrate peptide peak and a new 
Fig. 1. Sphingosine-induced suppression of cell viability. NCI-H28 (A), NCI-H2052 (B), NCI-H2452 (C), and MSTO-211H cells (D) were treated with sphingosine at concentrations as indicated for 24-48 $\mathrm{h}$, and then, MTT assay was carried out. In the graphs, each point represents the mean ( \pm SEM) percentage of basal cell viabilities (MTT intensities before treatment with sphingosine $)(n=4$ independent experiments).
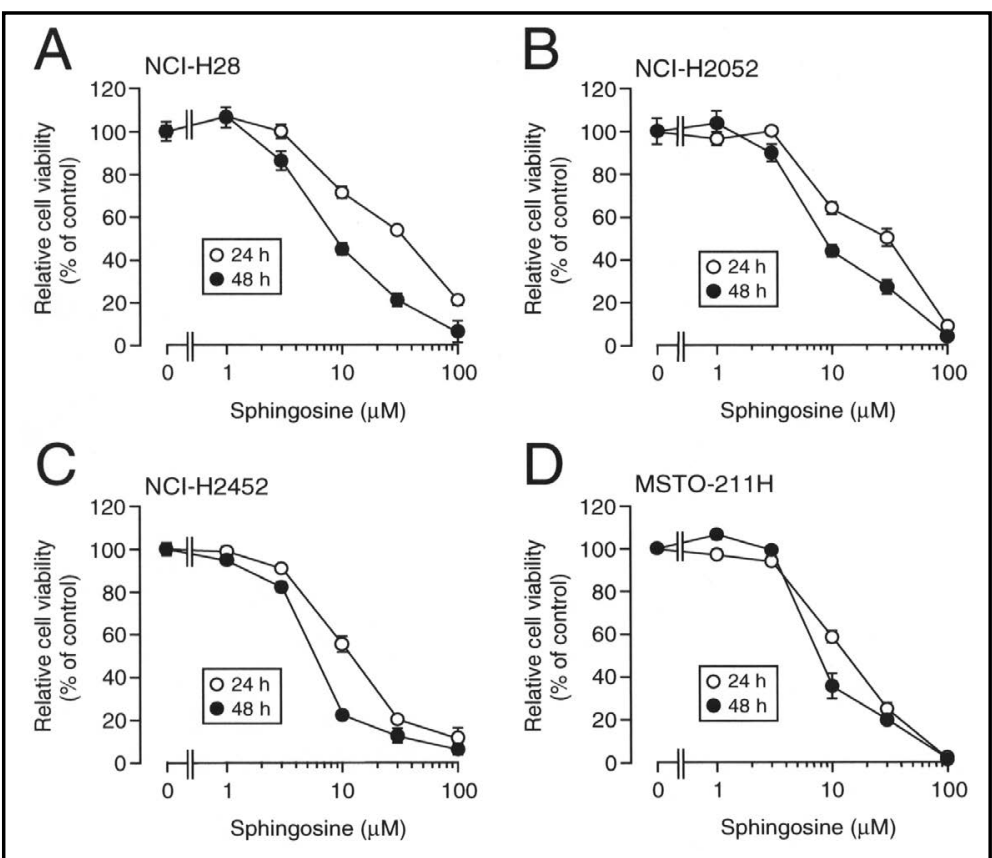

product peak were detected at an absorbance of $214 \mathrm{~nm}$. Areas for non-phosphorylated and phosphorylated PKC substrate peptide were measured (total area corresponds to concentration of PKC substrate peptide used here), and the amount of phosphorylated substrate peptide was calculated. Phosphorylated substrate peptide (pmol/1 min) was used as an index of PKC- $\delta$ activity.

\section{Construction and transfection of SiRNA}

The siRNA to silence PKC- $\delta$-targeted gene (PKC- $\delta$ siRNA) and the negative control siRNA (NC siRNA) were obtained from BONAC (Fukuoka, Japan). The PKC- $\delta$ siRNA and the NC siRNA were reverse-transfected into cells using a Lipofectamine reagent (Invitrogen, Carlsbad, CA, USA). Cells were used for experiments 48 $\mathrm{h}$ after transfection.

\section{Western blotting}

Cells were lysed with $1 \%(\mathrm{w} / \mathrm{v})$ sodium dodecyl sulfate (SDS). Proteins were separated by SDSpolyacrylamide gel electrophoresis (SDS-PAGE) using a TGX gel (BioRad, Hercules, CA, USA) and then transferred to polyvinylidene difluoride membranes. Blotting membranes were blocked with TBS-T [150 $\mathrm{mM} \mathrm{NaCl}, 0.1 \%(\mathrm{v} / \mathrm{v})$ Tween20 and $20 \mathrm{mM}$ Tris, $\mathrm{pH} 7.5$ ] containing 5\% (w/v) bovine serum albumin and subsequently incubated with an anti-PKC- $\delta$ antibody (Santa Cruz Biotechnology, Santa Cruz, CA, USA) or an anti- $\beta$-actin antibody (Sigma, St Louis, MO, USA). After washing, membranes were reacted with a horseradish peroxidase-conjugated goat anti-mouse IgG or goat anti-rabbit IgG antibody. Immunoreactivity was detected with an ECL kit (GE Healthcare, Piscataway, NJ, USA) and visualized using a chemiluminescence detection system (GE Healthcare). Protein concentrations for each sample were determined with a BCA protein assay kit (Pierce, Rockford, IL, USA).

\section{Statistical analysis}

Statistical analysis was carried out using Fisher's Protected Least Significant Difference (PLSD) test, unpaired $t$-test, and Dunnett's test.

\section{Results}

Sphingosine suppresses mesothelioma cell proliferation

For all the mesothelioma cells examined here treatment with sphingosine for 24-48 $\mathrm{h}$ decreased the number of viable cells in a concentration (1-100 $\mu \mathrm{M})$-dependent manner, 
Fig. 2. The effect of S1P on cell viability. NCI-H28 (A), NCI-H2052 (B), NCI-H2452 (C), and MSTO-211H cells (D) were treated with S1P at concentrations as indicated for 24-48 $\mathrm{h}$, and then, MTT assay was carried out. In the graphs, each point represents the mean \pm SEM) percentage of basal cell viabilities (MTT intensities before treatment with S1P) $(n=4 \quad$ independent experiments).
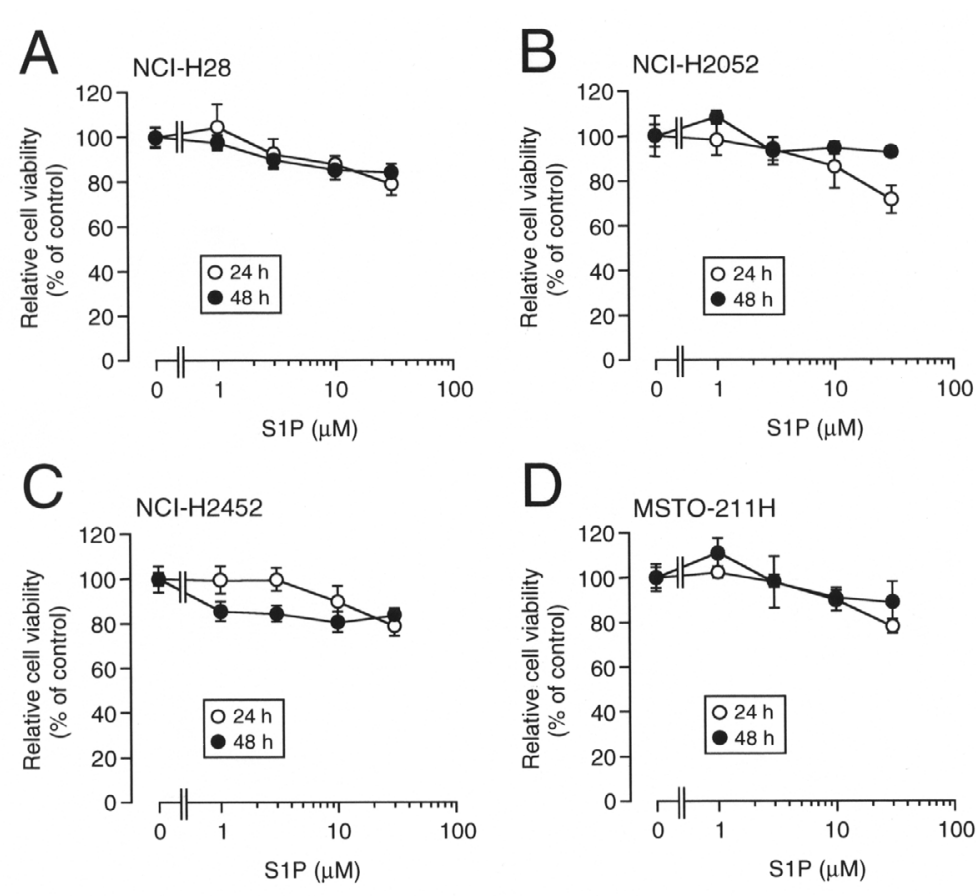

Fig. 3. The effect of sphingosine on SDK production. NCI-H28 (A), NCI-H2052 (B), NCI-H2452 (C), and MSTO-211H cells (D) were treated with sphingosine $(100 \mu \mathrm{M})$ for $0-6 \mathrm{~h}$, and Western blotting was carried out using an anti-PKC- $\delta$ antibody. Note that no increase in the SDK production (arrows) was found with sphingosine treatment and that similar results were obtained with 4 independent experiments.

\section{A $\mathrm{NCl}-\mathrm{H} 28$}
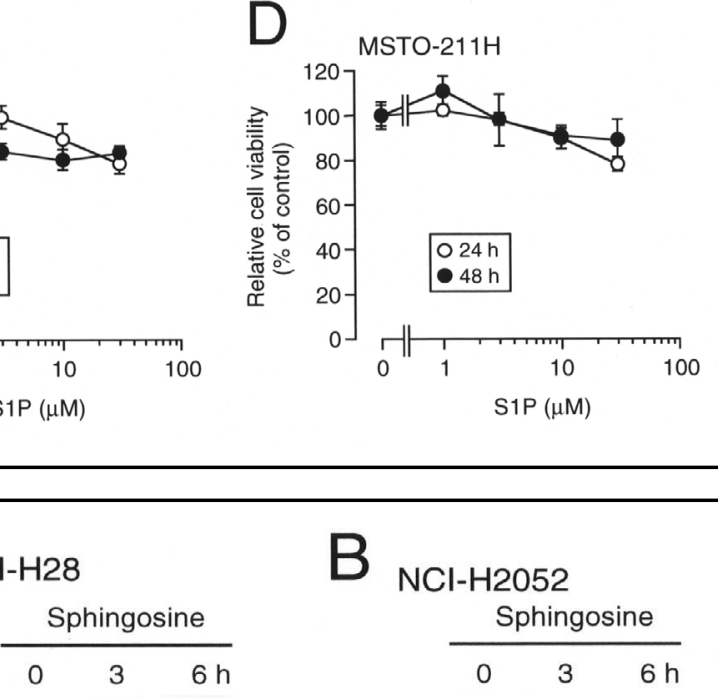

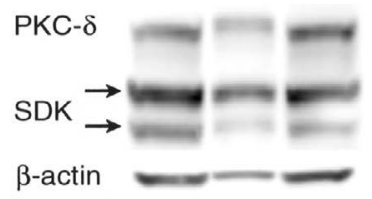

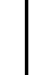

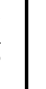 西 cis

\footnotetext{
cin
}

C

$\mathrm{NCl}-\mathrm{H} 2452$ Sphingosine
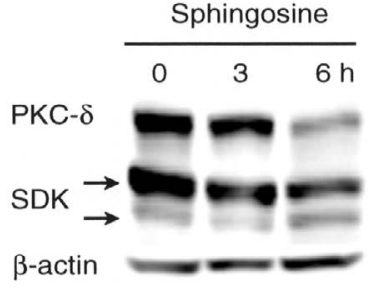
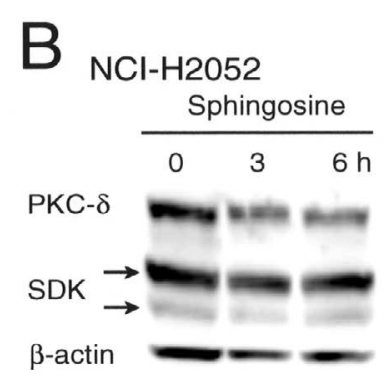

$D_{\text {MSTO-211H }}$

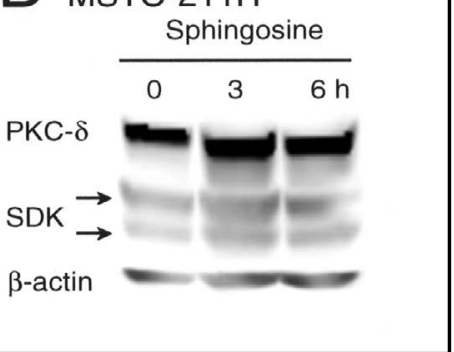

without difference in the extent among the cell types (Fig. 1A, B, C, D). In the terminal deoxynucleotidyl transferase-mediated dUTP nick end labeling (TUNEL) staining, no significant increase in TUNEL-positive cells was obtained with sphingosine for all the cell types (data not shown). This suggests that sphingosine do not induce mesothelioma cell apoptosis but suppresses mesothelioma cell proliferation.

Sphingosine is phosphorylated by sphingosine kinase 1 to produce S1P. Treatment with S1P for 24-48 h had little effect on the number of viable cells at concentrations ranging from 1 to $30 \mu \mathrm{M}$ for all the cell types (Fig. 2A, B, C, D). This indicates that sphingosine by itself, but not S1P produced from sphingosine, has the potential to suppress mesothelioma cell proliferation. 
Fig. 4. The effect of rottlerin on sphingosine-induced suppression of cell viability. NCI-H28 (A), NCI-H2052 (B), NCI-H2452 (C), and MSTO-211H cells (D) were treated with sphingosine at concentrations as indicated in the presence and absence of rottlerin $(10 \mu \mathrm{M})$ for $24 \mathrm{~h}$, and then, MTT assay was carried out. In the graphs, each point represents the mean ( \pm SEM) percentage of basal cell viabilities (MTT intensities before treatment with sphingosine in the absence of rottlerin)( $n=4$ independent experiments).
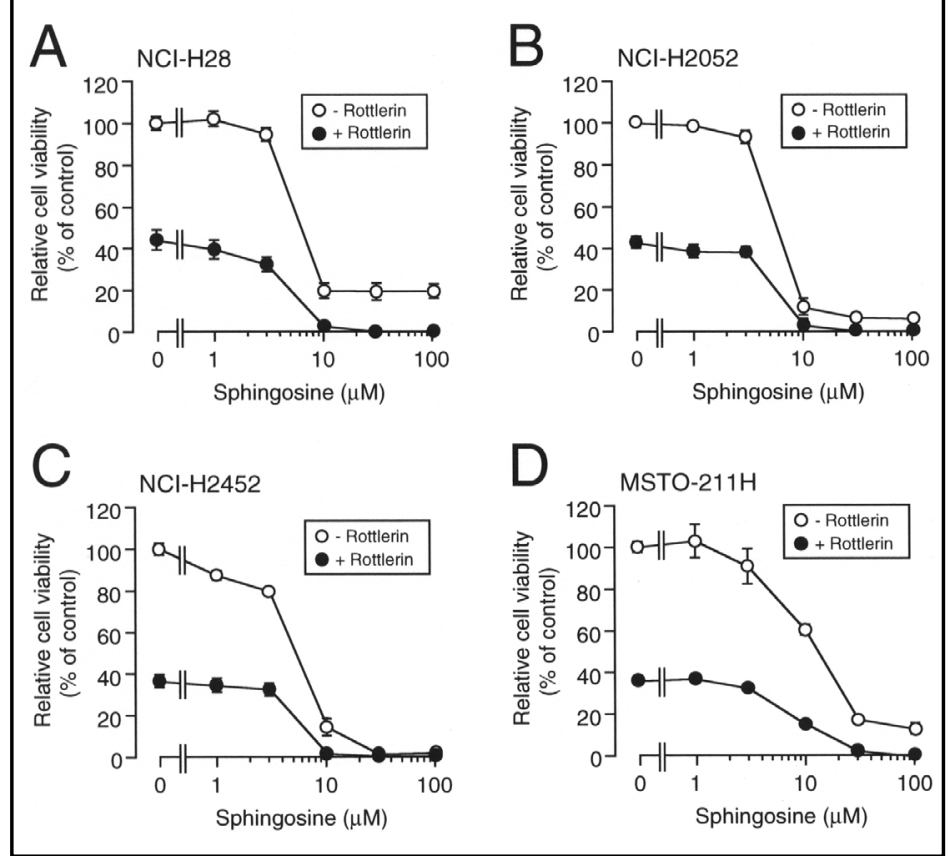

Fig. 5. Rottlerin-induced suppression of cell viability. NCI-H28 (A), NCI-H2052 (B), NCI-H2452 (C), and MSTO$211 \mathrm{H}$ cells (D) were treated with rottlerin alone at concentrations as indicated for 24-48 h, and then, MTT assay was carried out. In the graphs, each point represents the mean $( \pm$ SEM) percentage of basal cell viabilities (MTT intensities before treatment with rottlerin) ( $n=4$ independent experiments).
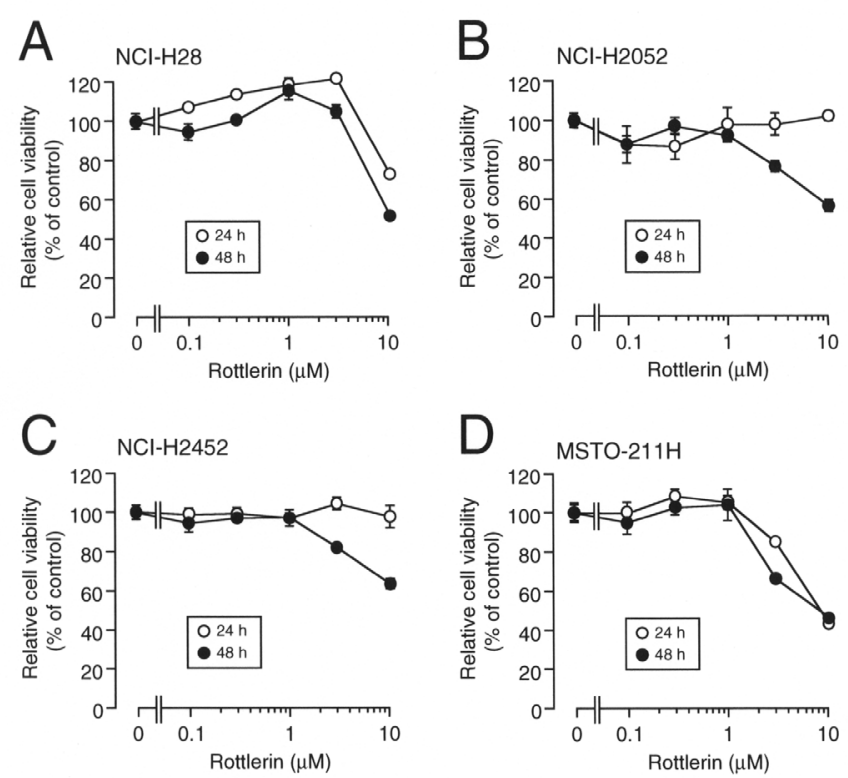

In our earlier study, sphingosine induced apoptosis in hippocampal neurons and astrocytes via a PKC- $\delta /$ SDK pathway [1]. We subsequently examined whether the sphingosine effect is due to $\mathrm{PKC}-\delta / \mathrm{SDK}$ activation. Sphingosine did not increase SDK production in all the cell types (Fig. 3A, B, C, D), ruling out the participation of SDK in the sphingosine effect here. Sphingosine-induced decrease in the number of viable cells was not inhibited by rottlerin $(10 \mu \mathrm{M})$, an inhibitor of PKC- $\delta$; conversely, further decrease in the number of viable cells was found in the presence of rottlerin $(\mathrm{P}<0.001$ as compared with the effect of sphingosine in the absence of rottlerin for all the cell types, Fisher's PLSD test)(Fig. 4A, B, $\mathrm{C}$, D). Moreover, treatment with rottlerin alone for 24-48 $\mathrm{h}$ decreased the number of viable cells in a concentration (0.1-10 $\mu \mathrm{M}$ )-dependent manner for all the cell types (Fig. 5A, B, C, 
Fig. 6. Sphingosine-induced PKC- $\delta$ inhibition. In the cellfree systems, PKC- $\delta$ activity was assayed in the presence and absence of sphingosine (100 $\mu \mathrm{M})$. In the graph, each column represents the mean $( \pm \mathrm{SEM})$ PKC- $\delta$ activity (pmol/min) $(\mathrm{n}=4)$. $P$ value, unpaired $t$-test.

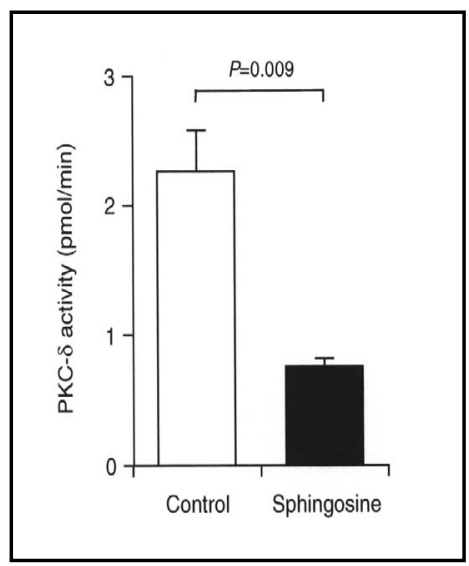

Fig. 7. The effect of PKC- $\delta$ knockdown on cell viability. MTT assay was carried out in NCI-H28 (A), NCI-H2052 (B), NCI-H2452 (C), and MSTO-211H cells (D) transfected with the NC siRNA (NC) or the PKC- $\delta$ siRNA (PKC- $\delta$ KD). Note that expression of PKC- $\delta$ is drastically decreased in all the cell types transfected with the PKC- $\delta$ siRNA in the Western blot analysis. In the graphs, each point represents the mean $( \pm$ SEM) percentage of basal cell viabilities (MTT intensities for cells transfected with NC siRNA at $48 \mathrm{~h}$ after transfection)( $\mathrm{n}=4$ independent experiments). $P$ values, Fisher's PLSD test.

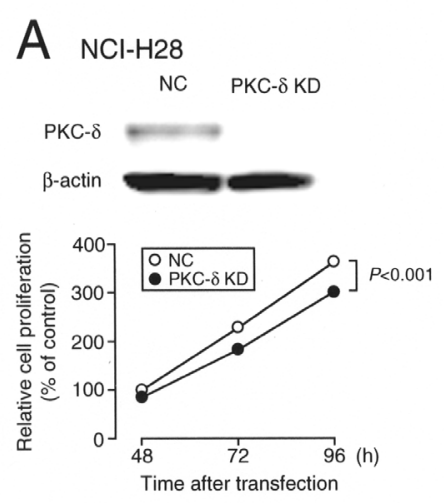

B NCl-H2052

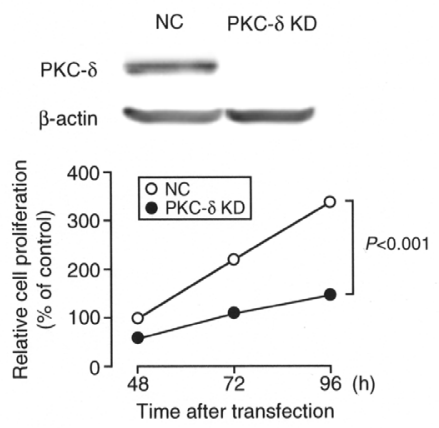

C $\mathrm{NCl}-\mathrm{H} 2452$ NC PKC- $\delta$ KD
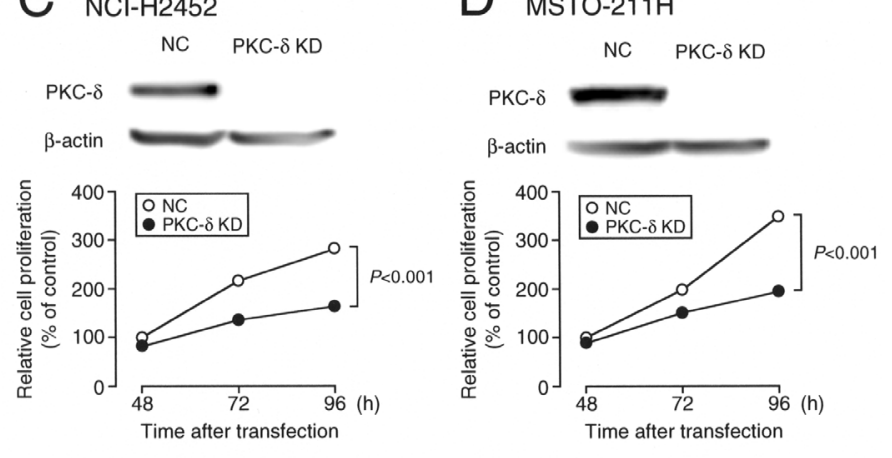

D). Taken together, these results suggest that PKC- $\delta$ promotes proliferation of mesothelioma cells. Then, we postulated that sphingosine might suppress proliferation of mesothelioma cells by inhibiting PKC- $\delta$.

\section{Mesothelioma cell proliferation is suppressed by inhibiting PKC- $\delta$}

To obtain evidence for sphingosine-induced PKC- $\delta$ inhibition, we carried out cell-free PKC assay. PKC- $\delta$ activity in the absence of sphingosine was $2.26 \pm 0.32 \mathrm{pmol} / \mathrm{min}$, but the activity was significantly attenuated in the presence of sphingosine $(0.76 \pm 0.06 \mathrm{pmol} / \mathrm{min})$ (Fig. 6). This confirms that sphingosine inhibits PKC- $\delta$.

For cells transfected with the PKC- $\delta$ siRNA, expression of PKC- $\delta$ protein was clearly reduced than the expression for cells transfected with NC siRNA (Fig. 7A, B, C, D), confirming PKC- $\delta$ knock-down. Spontaneous mesothelioma cell growth was significantly inhibited 
Fig. 8. The effect of PKC- $\delta$ knockdown on cell cycling. NCI-H28(A), NCI-H2052 (B), NCI-H2452 (C), and MSTO-211H cells (D) were transfected with the NC siRNA (NC) or the PKC- $\delta$ siRNA (PKC- $\delta$ $\mathrm{KD}$ ), and $72 \mathrm{~h}$ later cell cycle analysis was carried out. In the graphs, each column represents the mean $( \pm$ SEM) percentage for phases of cell cycling $(n=4$ independent experiments). $P$ values, Dunnett's test.

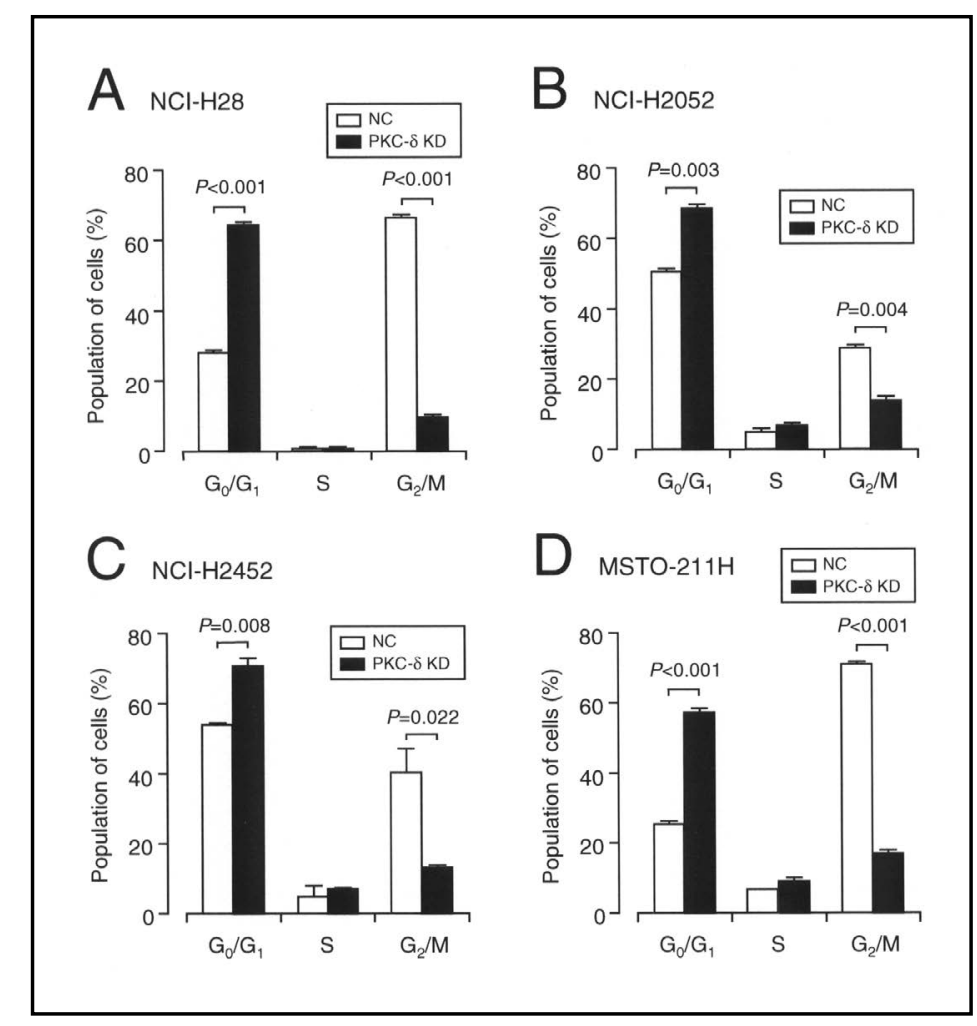

by knocking-down PKC- $\delta$, with the order of the potential: NCI-H2052 cells=MSTO-211H cells $>$ NCI-H2452 cells $>>$ NCI-H28 cells (Fig. 7A, B, C, D). This indicates that PKC- $\delta$ promotes mesothelioma cell proliferation.

Sphingosine suppresses mesothelioma cell proliferation by inducing cell cycle arrest at the $G_{0} / G_{1}$ phase

In the cell cycle analysis, knocking-down PKC- $\delta$ significantly increased the population of cells at the $G_{0} / G_{1}$ phase of cell cycling, but it otherwise decreased the population at the $\mathrm{G}_{2} / \mathrm{M}$ phase for all the cell types (Fig. 8). This implies that PKC- $\delta$ accelerates cell cycling for mesothelioma cells, i.e., inhibiting PKC- $\delta$ causes cell cycle arrest at the $G_{0} / G_{1}$ phase.

\section{Discussion}

The results of the present study demonstrate that sphingosine suppresses mesothelioma cell proliferation. Sphingosine is recognized to bind to and activate SDK, that is produced through proteolytic processing of PKC- $\delta$ [2]. Sphingosine induces apoptosis in hippocampal neurons and astrocytes by activating SDK, to phosphorylate 14-3-3 protein, thereby dissociating Bax and disrupting mitochondrial membrane potentials, and then leading to activation of caspase- 9 and the effector caspase-3 [1]. In the present study, sphingosine did not increase SDK production, which would exclude the possibility for the implication of SDK in sphingosine-induced suppression of mesothelioma cell proliferation.

Of PKC isozymes cloned PKC- $\delta$ as well as the other novel PKCs including PKC- $\varepsilon,-\eta,-\theta$, and $-\mu$, is activated by signaling cascades linked to phospholipase $\mathrm{A}_{2}$ in a $\mathrm{Ca}^{2+}$-independent manner [7, 8]. PKC- $\delta$ is activated by translocation towards the membrane surface [9]. Sphingosine inhibits PKC activation induced by diacylglycerol, phorbol dibutyrate, calcium, unsaturated fatty acids or other lipids $[10,11]$. PKC binds to membranes through interactions with diacylglycerol and negatively charged phosphatidylserine. Sphingosine may be localized 
in regions of acidic lipids, thereby inhibiting PKC binding to membranes and activity [1215]. Sphingosine, alternatively, inhibits the enzyme phosphatidic acid phosphohydrolase, that generates diacylglycerol production from phosphatidic acid produced by phospholipase D-catalyzed hydrolysis of phosphatidylcholine [16-18]. In the cell-free PKC assay, sphingosine attenuated PKC- $\delta$ activity. This indicates that sphingosine inhibits PKC- $\delta$ through its direct binding. Notably, rottlerin, an inhibitor of PKC- $\delta$, further enhanced sphingosine-induced suppression of mesothelioma cell growth or rottlerin alone without sphingosine inhibited mesothelioma cell growth. Moreover, knocking-down PKC- $\delta$ significantly suppressed mesothelioma cell growth. It is indicated from these results that sphingosine suppresses mesothelioma cell proliferation by inhibiting PKC- $\delta$. In the cell cycle analysis, knocking-down PKC- $\delta$ induced cell cycle arrest at the $\mathrm{G}_{0} /{ }_{1}$ phase for all the cell types used here. Overall, these results lead to a conclusion that sphingosine suppresses mesothelioma cell proliferation by inhibiting PKC- $\delta$, to induce cell cycle arrest at the $\mathrm{G}_{0} /{ }_{1}$ phase.

Lines of evidence have pointed to the contrasting roles of PKC- $\delta$ in cell survival and cell death [19]. The pro- and anti-apoptotic function of PKC- $\delta$ not only depends on the cell type but also on the stimulus. PKC- $\delta$ promotes survival of a variety of cancer cells such as nonsmall cell lung cancer, breast cancer, pancreatic cancer, liver cancer, and chronic lymphocytic leukemia cells. PKC- $\delta$ protects glioma cells from the apoptosis induced by TRAIL, and phosphorylation of PKC- $\delta$ on Tyr155 and its cleavage are essential for the anti-apoptotic effect of PKC- $\delta[20]$. Phosphorylation of PKC- $\delta$ at Tyr332 is also required for protection against TRAIL-induced apoptosis [21]. Overexpression of PKC- $\delta$ increases cell proliferation, anchorage-independent growth, and resistance to apoptotic stimuli by elevating cyclin D1 level and hyperphosphorylating Rb in murine mammary NMuMG cells [22]. Conversely, PKC- $\delta$ antisense oligonucleotide and dominant-negative PKC- $\delta$ decrease survival of breast cancer MCF-7 and MDA-MB-231 cells [23]. As found with the present study, rottlerin enhances apoptosis in non-small cell lung cancer cells [24]. Rottlerin blocks DNA damageinduced apoptosis, but otherwise it potentiates receptor-induced apoptosis [25].

$\mathrm{PKC}-\delta$ promotes cell survival via several well-known pro-survival pathways, that include NF- $\mathrm{kB}, \mathrm{Akt}$, and ERK. PKC- $\delta$ prevents apoptosis in colon cancer cells by inducing inhibitor of apoptosis protein-2 and FLICE-like inhibitory protein via NF- $\mathrm{B}[26,27]$. PKC- $\delta$ suppresses autophagy in breast cancer cells via NF- $\mathrm{B}$ [28]. Tumor necrosis factor (TNF) is recognized to induce translocation of PKC- $\delta$ to the nucleus, where it bound to the NF$\kappa B$ RelA subunit and induced transactivation of p65/RelA [29]. PKC- $\delta$ protects MCF-7 breast cancer cells against TNF-related apoptosis-inducing ligand-mediated apoptosis [30]. Phosphoinositide-dependent kinase- 1 may also participate in PKC- $\delta$ survival signaling in cells containing an activated p21Ras protein [31]. Activation of Akt and ERK, alternatively, is responsible for PKC- $\delta$-mediated increase in anchorage-independent growth and resistance of pancreatic ductal cancer cells to apoptotic stimuli [32]. PKC- $\delta$-induced cell proliferation in murine mammary cells is associated with activation of ERK/MAPK [22]. In contrast, PKC$\delta$-induced suppression of ERK1/2 is associated with the survival of MDA-MB-231 cells [33]. $\mathrm{PKC}-\delta$ attenuates apoptosis by inducing phosphorylation and proteasomal degradation of the proapoptotic protein Bim via the MEK/MAPK pathway in immortalized and malignant keratinocytes [34]. Syk, a tyrosine kinase, promotes survival of B-cell chronic lymphocytic leukemia cells by stabilizing Mcl- 1 in a PKC- $\delta$-dependent manner [35]. PKC- $\delta$ activated by Syk phosphorylates and inhibits glycogen synthase kinase-3, causing stabilization of Mcl1 and inhibition of apoptosis. It is presently unknown what signaling pathways underlie sphingosine/PKC- $\delta$-dependent inhibition of proliferation in mesothelioma cells. To address this question, we are carrying out further experiments.

In conclusion, the results of the present study show that sphingosine inhibits PKC- $\delta$, thereby inducing cell cycle arrest at the $\mathrm{G}_{0} /{ }_{1}$ phase, and then leading to suppression of mesothelioma cell proliferation. This may represent further insight into the sphingosine signaling pathway relevant to cell proliferation and death. 


\section{References}

1 Kanno T, Nishizaki T: Sphingosine induces apoptosis in hippocampal neurons and astrocytes by activating caspase-3/-9 via a mitochondrial pathway linked to SDK/14-3-3 protein/Bax/cytochrome c. J Cell Physiol 2011;226:2329-2337.

2 Suzuki E, Handa K, Toledo MS, Hakomori S: Sphingosine-dependent apoptosis: a unified concept based on multiple mechanisms operating in concert. Proc Natl Acad Sci USA 2004;101:14788-14793.

-3 Hamaguchi A, Suzuki E, Murayama K, Fujimura T, Hikita T, Iwabuchi K, Handa K, Withers DA, Masters SC, Fu $\mathrm{H}$, Hakomori S: A sphingosine-dependent protein kinase that specifically phosphorylates 14-3-3 (SDK1) is identified as the kinase domain of PKC $\delta$ : a preliminary note. Biochem Biophys Res Commun 2003;307:589594.

4 Hamaguchi A, Suzuki E, Murayama K, Fujimura T, Hikita T, Iwabuchi K, Handa K, Withers DA, Masters SC, Fu H, Hakomori S: Sphingosine-dependent protein kinase-1, directed to 14-3-3, is identified as the kinase domain of protein kinase C $\delta$. J Biol Chem 2003;278:41557-41565.

5 Phillips DC, Martin S, Doyle BT, Houghton JA: Sphingosine-induced apoptosis in rhabdomyosarcoma cell lines is dependent on pre-mitochondrial Bax activation and post-mitochondrial caspases. Cancer Res 2007;67:756-764.

6 Shimizu T, Kanno T, Tanaka A, Nishizaki T: $\alpha, \beta$-DCP-LA selectively activates PKC- $\varepsilon$ and stimulates neurotransmitter release with the highest potency among 4 diastereomers. Cell Physiol Biochem 2011;27:149-158.

7 Nishizuka Y: Intracellular signaling by hydrolysis of phospholipids and activation of protein kinase C. Science 1992;258:607-614.

-8 Nishizuka Y: Protein kinase C and lipid signaling for sustained cellular responses. FASEB J 1995;9:484-496.

-9 Steinberg SF: Distinctive activation mechanisms and functions for protein kinase $\mathrm{C} \delta$. Biochem J 2004;384:449-459.

-10 Hannun YA, Loomis CR, Merrill AH Jr, Bell RM: Sphingosine inhibition of protein kinase C activity and of phorbol dibutyrate binding in vitro and in human platelets. J Biol Chem 1986;261:12604-12609.

11 el Touny S, Khan W, Hannun Y: Regulation of platelet protein kinase C by oleic acid. Kinetic analysis of allosteric regulation and effects on autophosphorylation, phorbol ester binding, and susceptibility to inhibition. J Biol Chem 1990;265:16437-16443.

12 Merrill AH Jr, Sereni AM, Stevens VL, Hannun YA, Bell RM, Kinkade JM Jr: Inhibition of phorbol esterdependent differentiation of human promyelocytic leukemic (HL-60) cells by sphinganine and other longchain bases. J Biol Chem 1986;261:12610-12615.

13 Merrill AH Jr, Nimkar S, Menaldino D, Hannun YA, Loomis C, Bell RM, Tyagi SR, Lambeth JD, Stevens VL, Hunter R, Liotta DC: Structural requirements for long-chain (sphingoid) base inhibition of protein kinase C in vitro and for the cellular effects of these compounds. Biochemistry 1989;28:3138-3145.

14 Bazzi MD, Nelsestuen GL: Mechanism of protein kinase C inhibition by sphingosine. Biochem Biophys Res Commun 1987;146:203-207.

15 Smith ER, Jones PL, Boss JM, Merrill AH Jr: Changing J774A.1 cells to new medium perturbs multiple signaling pathways, including the modulation of protein kinase $\mathrm{C}$ by endogenous sphingoid bases. J Biol Chem 1997;272:5640-5646.

-16 Nakamura T, Abe A, Balazovich KJ, Wu D, Suchard SJ, Boxer LA, Shayman JA: Ceramide regulates oxidant release in adherent human neutrophils. J Biol Chem 1994;269:18384-18389.

$\checkmark 17$ Merrill AH Jr, Hannun YA, Bell RM: Introduction: Sphingolipids and their metabolites in cell regulation. Adv Lipid Res 1993;25:1-24.

-18 Raeder EM, Mansfield PJ, Hinkovska-Galcheva V, Kjeldsen L, Shayman JA, Boxer LA: Sphingosine blocks human polymorphonuclear leukocyte phagocytosis through inhibition of mitogen-activated protein kinase activation. Blood 1999;93:686-693.

19 Basu A, Pal D: Two faces of protein kinase C $\delta$ : the contrasting roles of PKC $\delta$ in cell survival and cell death. ScientificWorldJournal 2010;10:2272-2284.

20 Okhrimenko H, Lu W, Xiang C, Ju D, Blumberg PM, Gomel R, Kazimirsky G, Brodie C: Roles of tyrosine phosphorylation and cleavage of protein kinase $C \delta$ in its protective effect against tumor necrosis factorrelated apoptosis inducing ligand-induced apoptosis. J Biol Chem 2005;280:23643-23652. 
Okuwa/Kanno/Fujita et al.: Sphingosine-Induced Cell Cycle Arrest

21 Lu W, Lee HK, Xiang C, Finniss S, Brodie C: The phosphorylation of tyrosine 332 is necessary for the caspase 3-dependent cleavage of PKC $\delta$ and the regulation of cell apoptosis. Cell Signal 2007;19:2165-2173.

22 Grossoni VC, Falbo KB, Kazanietz MG, de Kier Joffe ED, Urtreger AJ: Protein kinase C $\delta$ enhances proliferation and survival of murine mammary cells. Mol Carcinog 2007;46:381-390.

23 McCracken MA, Miraglia LJ, McKay RA, Strobl JS: Protein kinase C $\delta$ is a prosurvival factor in human breast tumor cell lines. Mol Cancer Ther 2003;2:273-281.

-24 Clark AS,West KA, Blumberg PM, Dennis PA: Altered protein kinase C (PKC) isoforms in non-small cell lung cancer cells: PKC $\delta$ promotes cellular survival and chemotherapeutic resistance. Cancer Res 2003;63:780786.

25 Basu A, Miura A: Differential regulation of extrinsic and intrinsic cell death pathways by protein kinase C. Int J Mol Med 2002;10:541-545.

26 Wang Q, Wang X, Evers BM: Induction of cIAP-2 in human colon cancer cells through PKC delta/NF- $\mathrm{KB}$. J Biol Chem 2003;278:51091-51099.

27 Wang Q, Wang X, Zhou Y, Evers BM: PKC $\delta$-mediated regulation of FLIP expression in human colon cancer cells. Int J Cancer 2006;118:326-334

-28 Mann AP, Verma A, Sethi G, Manavathi B, Wang H, Fok JY, Kunnumakkara AB, Kumar R, Aggarwal BB, Mehta $\mathrm{K}$ : Overexpression of tissue transglutaminase leads to constitutive activation of nuclear factor- $\mathrm{\kappa B}$ in cancer cells: delineation of a novel pathway. Cancer Res 2006;66:8788-8795.

29 Lu ZG, Liu H, Yamaguchi T, Miki Y, Yoshida K: Protein kinase C $\delta$ activates RelA/p65 and nuclear factor-кB signaling in response to tumor necrosis factor- $\alpha$. Cancer Res 2009;69:5927-5935.

-30 Zhang J, Liu N, Liu S, Liu Y, Zheng D: PKC $\delta$ protects human breast tumor MCF-7 cells against tumor necrosis factor-related apoptosis-inducing ligand-mediated apoptosis. J Cell Biochem 2005;96:522-532.

-31 Xia S, Chen Z, Forman LW, Faller DV: PKC $\delta$ survival signaling in cells containing an activated p21Ras protein requires PDK1. Cell Signal 2009;21:502-508.

32 Mauro LV, Grossoni VC, Urtreger AJ, Yang C, Colombo LL, Morandi A, Pallotta MG, Kazanietz MG, Bal de Kier Joffe ED, Puricelli LL: PKC Delta (PKC $\delta$ ) promotes tumoral progression of human ductal pancreatic cancer. Pancreas 2010;39: e31-41.

33 Lonne GK, Masoumi KC, Lennartsson J, Larsson C: Protein kinase C $\delta$ supports survival of MDA-MB-231 breast cancer cells by suppressing the ERK1/2 pathway. J Biol Chem 2009;284:33456-33465.

34 Quadros MR, Connelly S, Kari C, Abrams MT, Wickstrom E, Rodeck U: EGFR-dependent downregulation of Bim in epithelial cells requires MAPK and PKC- $\delta$ activities. Cancer Biol Ther 2006;5:498-504.

35 Baudot AD, Jeandel PY, Mouska X, Maurer U, Tartare-Deckert S, Raynaud SD, Cassuto JP, Ticchioni M, Deckert M: The tyrosine kinase Syk regulates the survival of chronic lymphocytic leukemia B cells through -PKC $\delta$ and proteasome-dependent regulation of Mcl-1 expression. Oncogene 2009;28:3261-3273. 